\title{
Akses Pangan dan Kejadian Balita Stunting : Kasus Pedesaan Pertanian di Klaten
}

\author{
Food Access and Stunting incidence: a Case Study of Rural \\ Agriculture in Klaten
}

Vanda Ningrum

Pusat Penelitian Kependudukan, Lembaga Ilmu Pengetahuan Indonesia
Email : vanda.ningrum@gmail.com

Diterima : 30 Januari 2019

Revisi : 25 Maret 2019

Disetujui : 29 Maret 2019

\section{ABSTRAK}

Akses pangan di tingkat rumah tangga masih menjadi salah satu permasalahan utama yang berkontribusi pada terjadinya balita stunting. Penelitian ini bertujuan untuk menganalisis ketahanan rumah tangga dalam mengakses pangan yang dipengaruhi oleh faktor budaya, sosial, dan ekonomi serta dampaknya terhadap kondisi stunting dengan mengambil kasus di 4 Desa Kabupaten Klaten Jawa Tengah. Metode pengambilan data menggunakan kombinasi teknik kuantitatif dan kualitatif seperti survei rumah tangga, wawancara mendalam, observasi, dan diskusi terfokus. Hasil penelitian menunjukkan adanya perubahan perilaku konsumsi dalam mengakses dan mengelola pangan keluarga yang dipengaruhi oleh modernisasi di pedesaan, yaitu meningkatnya budaya membeli makanan matang dan perubahan produksi pertanian menjadi monokultur. Selanjutnya, masalah terbesar bagi penduduk untuk memenuhi nutrisi adalah keterbatasan ekonomi dalam membeli makanan yang beragam dan bergizi. Keterbatasan ini berdampak langsung pada kebiasaan konsumsi pangan yang beragam, pada keluarga dengan balita stunting cenderung tidak menyukai makanan yang beragam khususnya sayur mayur dan makanan yang berasal dari laut. Membiasakan masyarakat untuk mengonsumsi pangan yang beragam tidak cukup hanya dengan program sosialisasi, namun juga perlu dimulai dari meningkatkan kemampuan rumah tangga untuk mendapatkan pangan yang beragam melalui bantuan non tunai pangan baik dalam bentuk karbohidrat maupun protein. Selain itu, memperluas akses pangan keluarga dapat dilakukan dengan membudayakan kembali pemanfaatan lahan pekarangan untuk budidaya pangan.

kata kunci : akses pangan, balita, stunting

\section{ABSTRACT}

Household food access is still one of the main problems that contribute to stunting incident. This paper aims to analyze household food security in accessing food that is influenced by cultural, social and economic factors then its impact on stunting conditions in four rural agriculture in Klaten Central Java. The data collection method used a combination of quantitative and qualitative techniques such as household surveys, in-depth interviews, direct observation, and focused discussions. The results showed the modernization had influenced the changing in food consumption behavior of household and child under five years in the countryside such as the growing culture of buying processed food and changing agricultural production became a monoculture. Furthermore, the biggest problem to fulfill nutrition for the family is the limitation of purchasing power, and it has a direct impact on combination food consumption habits especially vegetables and seafood. Getting people to consume a variety of foods is not only by socialization program but also needs to increase the ability of households to obtain diverse food through an in-kind transfer of carbohydrates and proteins. Also, expanding family food access can be done by re-cultivating the use of household land.

keywords : food access, the child under five years, stunting 


\section{PENDAHULUAN} Kajian akses pangan masih menjadi isu akademik. Hal tersebut disebabkan akses pangan berhubungan dengan kemiskinan dan kelaparan. Selain itu, akses pangan berpengaruh pada kecukupan gizi pada balita dan dapat berpengaruh pada kualitas sumber daya manusia di masa depan. Data kekurangan gizi pada balita (bayi di bawah 5 tahun) yang dilaporkan oleh UNICEF, WHO, dan World Bank (2015) masih menunjukkan angka yang tinggi dibandingkan dengan target yang diharapkan, yaitu 151 juta balita atau 22,2 persen balita di dunia mengalami stunting (UNICEF, WHO, dan World Bank, 2018). Stunting atau yang dikenal dengan pengertian balita pendek adalah kondisi gagal tumbuh anak balita yang disebabkan kekurangan gizi kronis sehingga tubuh anak terlalu pendek untuk usianya (Infodatin, 2016). Di Indonesia, tingkat prevalensi stunting 2018 masih menunjukkan angka yang sangat tinggi, yaitu sebesar 30,8 (Kemenkes, 2018). Hal tersebut berarti satu dari tiga balita di Indonesia mengalami stunting. Meskipun angka ini telah turun dibandingkan dengan prevalensi stunting di tahun 2013 (37,2 persen), namun masih lebih tinggi dari batas toleransi stunting yang ditetapkan oleh WHO, yaitu maksimal 20 persen.

Pada pemerintah JOKOWI-JK, program pangan dan gizi telah menjadi prioritas melalui RPJMN 2015-2019. Salah satu tujuan utama program tersebut adalah pengurangan angka stunting balita untuk menghasilkan sumber daya manusia yang berdaya saing. Permasalahan stunting sendiri merupakan masalah multidimensi. Salah satunya adalah akses pangan yang belum mencukupi kebutuhan pangan yang berimbang di tingkat rumah tangga. Akses tersebut tidak terlepas dari ketahanan pangan rumah tangga yang juga dipengaruhi oleh berbagai dimensi. Lembaga internasional (FAO) menetapkan ketahanan pangan rumah tangga berdasarkan kemampuan rumah tangga dalam mengakses pangan yang cukup untuk memenuhi nutrisi yang dibutuhkan. Aksesibilitas pangan mencakup aspek fisik, yaitu tersedia dan dapat diperoleh saat dibutuhkan. Dalam pengertian tersebut, aksesibilitas menggabungkan antara aspek produksi dalam penyediaan pangan dan aspek konsumsi dalam rumah tangga (Rachman, 2010). Hambatan yang terjadi pada aspek produksi, seperti kurangnya produksi pertanian dalam negeri, dapat mengurangi ketersediaan pangan suatu negara sehingga pemenuhan kebutuhan pangan dilakukan melalui impor. Dalam kasus impor, aspek ketersediaan tetap tercukupi, namun aspek kemandirian dan kedaulatan dalam penyediaan pangan masih dipertanyakan. Pada berbagai gerakan petani dan masyarakat sipil, kritik yang berkembang tentang aksesibilitas pangan tidak hanya dinilai dari ketersediaan secara fisik saja, namun juga dilihat dari produsen pangan, pendistribusian pangan, dan konsumen pangan sebagai suatu inti dalam sistem pangan (White, 2011).

Makanan yang diakses oleh rumah tangga tidak terlepas dari kebiasaan pangan yang sudah muncul sejak zaman nenek moyang, namun juga dipengaruhi oleh sistem pertanian yang berkembang di daerah tersebut. Kegagalan diversifikasi pertanian menyebabkan kegagalan dalam rumah tangga untuk mengakses pangan yang beragam sehingga berpengaruh pada kondisi kesehatan masyarakat, seperti stunting dan obesitas (Deller, dkk., 2017). Kebijakan penyediaan pangan yang beragam hasil pertanian lokal menjadi faktor yang perlu diperhatikan karena berpengaruh pada peningkatan akses masyarakat terhadap pangan yang beragam, peningkatan kedaulatan pangan, dan tidak terjebak dengan impor pangan. Ketergantungan penyediaan pangan impor juga menganggu kestabilan rumah tangga dalam akses pangan karena harga pangan sangat ditentukan oleh pasar global. Oleh karena itu, penguatan produksi pertanian lokal dan akses produk pangan lokal yang beragam berkontribusi dalam penguatan ketahanan pangan keluarga agar mencapai keseimbangan nutrisi yang dibutuhkan.

Pada tahun 2008, pemerintah telah menetapkan 100 kabupaten di Indonesia sebagai prioritas penanganan stunting. Tujuh puluh delapan kabupaten prioritas tersebut termasuk wilayah yang mempunyai anak balita 
stunting dengan angka yang cukup tinggi, salah satunya Kabupaten Klaten. Hal tersebut berkaitan dengan akses pemanfaatan pangan yang kurang untuk pemenuhan nutrisi ibu hamil dan anak balita, khususnya bagi penduduk miskin dan menengah ke bawah yang cukup tinggi di wilayah tersebut. Kurangnya akses pemanfaatan pangan disebabkan belum tercukupi penghasilan penduduk untuk memenuhi makanan yang bernutrisi. Empat puluh persen pengeluaran digunakan untuk membeli sereal (beras) sehingga kebutuhan untuk protein menjadi sangat kurang (BMKG, 2017).

Perilaku konsumsi juga menjadi penyebab penting dalam terjadinya stunting (Krasevec, dkk., 2016). Di pedesaan, perilaku konsumsi rumah tangga dipengaruhi modernisasi, yaitu terbukanya akses desa ke kota yang semakin terbuka menyebabkan kemudahan perdagangan makanan instan masuk ke pedesaan. Kondisi tersebut mempengaruhi budaya "jajan" bagi semua penduduk. Saat ini, kualitas makanan "jajan" diperdebatkan karena diyakini kurang mempunyai kandungan gizi yang baik. Sebuah studi menunjukkan bahwa anak yang mengkonsumsi jajanan lebih banyak mengandung lemak dalam tubuhnya (Dini, dkk., 2017). Fenomena modernisasi lainnya adalah meningkatnya kontribusi perempuan dalam pasar kerja di pedesaan karena masuknya pabrik-pabrik manufacturing. Kondisi tersebut menyebabkan waktu yang dimiliki ibu untuk memasak dan menyiapkan makanan bagi rumah tangga berkurang sehingga perilaku membeli makanan matang juga meningkat di pedesaan.

Pada penelitian ini, penulis akan memaparkan hasil analisis bagaimana ketahanan pangan rumah tangga dalam mengakses pangan dan perilaku konsumsi dipengaruhi oleh faktor budaya, sosial, dan ekonomi rumah tangga, serta bagaimana dampaknya terhadap kondisi stunting pada balita dengan mengambil kasus di Kabupaten Klaten, Jawa Tengah.

\section{METODOLOGI}

Studi ini dilakukan di empat desa Kabupaten Klaten Jawa Tengah dengan pertimbangan Klaten termasuk dalam kabupaten dengan angka stunting yang tinggi, yaitu 31,3 (Kemenkes, 2013). Pendekatan yang digunakan dalam menganalisis menggunakan kombinasi dua pendekatan. Pendekatan pertama adalah survei rumah tangga pada 62 rumah tangga yang mencakup 4 desa yaitu Desa Sumyang (Kecamatan Jogonalan), Desa Pandes, Birit, dan Canan (Kecamatan Wedi). Pendekatan tersebut bertujuan untuk medeskripsikan karakteristik demografi rumah. Teknik pengambilan data menggunakan purposive snowballing. Dalam penelitian ini, responden adalah ibu yang mempunyai anak berusia antara dua samapi dengan lima tahun. Kuesioner disusun terdiri dari beberapa sub bagian pertanyaan, yaitu i) karakteristik sosial demografi anggota rumah tangga, sumber ekonomi rumah tangga; ii) pemanfaatan sarana dan prasarana air bersih dan sanitasi; iii) akses pangan rumah tangga; dan iv) pola konsumsi pangan rumah tangga. Data sekunder berupa kejadian gizi buruk di tingkat kabupaten sampai dengan desa dikumpulkan dari berbagai dinas terkait, seperti Dinas Kesehatan, Badan Pusat Statistik dan lembaga atau instansi lainnya yang relevan. Selain itu, peneliti juga melakukan kajian literature dari penelitian sebelumnya untuk mempertajam analisis data.

Data kualitatif diperoleh dengan melakukan wawancara mendalam kepada 10 Ibu yang mempunyai balita stunting di Desa Sumyang. Wawancara dilakukan dengan sistem pertanyaan terbuka sehingga dapat menggali lebih lanjut dari setiap jawaban yang dikemukakan oleh responden. Variabel pertanyaan yang digunakan untuk wawancara, yaitu: i) jenis makanan yang dikonsumsi rumah tangga pada pagi, siang, dan malam; ii) bagaimana mereka memperoleh dan menyiapkan menu makanan tersebut; dan iii) siapa yang menentukan menu makanan di rumah tangga setiap harinya. Keakuratan data kualitatif diuji dengan validitas dan reabilitas data (Noble dan Smith, 2015). Validitas dilakukan dengan melakukan observasi langsung ke-10 rumah tangga yang mempunyai anak stunting dengan umur di bawah 5 tahun. Sementara, reliabilitas data diperoleh dengan studi literatur yang berhubungan dengan akses pangan keluarga 
dan balita stunting, serta serangkaian diskusi terfokus yang dilakukan di lokasi penelitian dengan melibatkan bidan desa, aparat kesehatan di kecamatan, dan akademisi pakar yang tergabung dalam Workshop Widyakarya Pangan dan Gizi 2018.

\section{HASIL DAN PEMBAHASAN}

\subsection{Akses dan Budaya Pangan di Kabupaten Klaten}

Pemilihan makanan suatu komunitas sangat erat kaitannya dengan hasil pertanian di wilayah setempat (Deller, dkk., 2017). Wilayah Asia bagian selatan yang cocok untuk pertanian padi sehingga beras menjadi makanan pokoknya. Sementara, Eropa dan Amerika dapat ditumbuhi gandum sehingga gandum menjadikan makanan pokoknya. Cara penyajian makanan hasil pertanian juga disesuaikan dengan nilai-nilai yang terkandung di dalam masyarakat tersebut. Di Jawa, beras terlebih dahulu dimasak dengan air sampai menjadi nasi setengah matang. Selanjutnya, nasi setengah matang dikukus sampai matang. Kegiatan tersebut merupakan proses memasak yang diperkenalkan pada masa praislami sebagai simbolis Baratayuda (Jákl, 2015). Meskipun pada masa modern saat ini, cara dan peralatan untuk memasak nasi tersebut telah digantikan dengan teknologi yang lebih modern, namun cita rasa dan hasil olahan tetap menyerupai kebiasaan dari nenek moyang sudah terinternalisasi pada generasi penerusnya.

Selain padi, sebelum masa revolusi hijau, petani Kabupaten Klaten juga menanam berbagai jenis pangan, seperti jagung, kedelai, tebu, dan holtikultura lainnya sehingga petani pada saat itu bersifat subsistence. Sejak kebijakan revolusi hijau, produksi padi ditargetkan untuk swasembada nasional sehingga mengubah seluruh areal pertanian di Klaten menjadi sawah dan sebagian kecil dijadikan kolam ikan. Saat ini, Klaten menjadi salah satu lumbung padi nasional untuk beras. Akses beras untuk konsumsi sehari-hari sudah dapat terpenuhi dari hasil pertanian lokal. Namun, kegagalan diversifikasi pertanian pangan lainnya membuat masyarakat Klaten sangat tergantung pada beras dan pemenuhan kebutuhan pangan lainnya harus dibeli dari luar wilayah. Pertanian subsistence juga sudah hampir menyusut karena para petani sudah menganggap pertanian sebagai usaha keluarga untuk mendapat penghasilan yang digunakan untuk keperluan sehari-hari, termasuk untuk memperoleh pangan.

Di pedesaan Kabupaten Klaten, sebagian besar rumah tangga memperoleh pangan sehari-hari dengan membeli, baik untuk kebutuhan protein maupun karbohidrat. Kebutuhan protein nabati diperoleh dari konsumsi tahu dan tempe. Sementara, kebutuhan protein hewani dari konsumsi unggas, seperti ayam dan bebek. Ikan dan jenis pangan laut lainnya, termasuk jenis pangan yang sedikit dikonsumsi. Hal tersebut disebabkan sebagian besar responden yang diwawancarai di desa menyatakan bahwa pengolahan ikan (memasak) membutuhkan waktu yang lebih lama dan kemampuan memasak yang lebih untuk menghasilkan cita rasa yang enak, meskipun ketersediaan ikan segar di pasar sangat banyak. Nutrisi sayuran sebagian besar juga diperoleh dengan membeli di pasar karena pekarangan yang dimiliki tidak digunakan untuk menanam sayuran. Saat dikunjungi oleh tim peneliti di Desa Sumyang, beberapa rumah yang mempunyai balita stunting terlihat tidak mempunyai halaman yang cukup untuk bercocok tanam di tanah dan sebagian masyarakat belum terbiasa untuk menanam dengan menggunakan tanaman di pot atau jenis hidroponik lainnya. Hal yang berbeda terjadi pada pemenuhan kebutuhan karbohidrat. Sebagian besar pemenuhan kebutuhan karbohidrat diperoleh dari beras yang diproduksi sendiri di Klaten. Sebagai salah satu wilayah lumbung padi nasional, Klaten mampu menyediakan beras yang cukup untuk kebutuhan penduduknya, bahkan sebagian besar mampu dijual di luar kabupaten.

Hasil wawancara yang dilakukan kepada responden yang telah berusia 60 tahun keatas, menyatakan bahwa mereka menyajikan makanan untuk keluarga dengan cara memasak sendiri. Sebagian besar kebutuhan sayuran diperoleh dengan menanam di pekarangan atau pematang sawah, sementara kebutuhan beras diperoleh dari sawah sendiri. Pemenuhan kebutuhan protein hewani berasal dari unggasn dari ternak sendiri dan dikonsumsi pada hari-hari tertentu saja, seperti hari raya atau saat ada kegiatan keluarga besar ataupun kegiatan kemasyarakatan. Budaya wanita menyediakan makanan untuk keluarga dengan memasak sendiri masih sangat kental dan kemampuan memasak bagi 
wanita pada zaman dahulu sangat penting, khusunya bagi wanita yang akan menikah.

Kondisi tersebut berbeda dengan saat ini. Hasil wawancara kepada ibu-ibu yang berusia antara 20-40 tahun yang mempunyai anak balita penderita stunting menunjukkan bahwa tidak seluruh makanan sehari-hari diperoleh dengan memasak. Sebagian pangan diperoleh dengan cara membeli makanan siap untuk disaji. Pada awalnya, budaya membeli makanan yang siap saji ini disebabkan ibu-ibu di desa juga bekerja di luar rumah untuk mencari pendapatan tambahan sehingga waktu yang dibutuhkan untuk kegiatan domestik rumah tangga menjadi berkurang.

Masuknya perempuan dalam dunia kerja di desa-desa klaten mempunyai dampak pada perubahan budaya dalam penyajian makanan keluarga. Perubahan ini dapat dilihat dari kacamata modernisasi yang terjadi di pedesaan, yaitu perubahan desa dari single activity, yaitu pertanian, menjadi multi activity yang mengandalkan kegiatan ekonomi dari kegiatan pertanian dan non-pertanian (Ningrum, 2017). Di era reformasi, proses modernisasi dapat dianalisis dari program pembangunan desa yang bergeser dari pendekatan top-down menjadi buttom-up melalui proyek pemberdayaan masyarakat desa (PMD). Selain pemberdayaan di sektor pertanian, program-program pemerintah juga mengarah pada sektor lainnya, seperti perdagangan, jasa, dan industri skala kecil dan menengah. Sampai dengan pemerintahan pascareformasi, pembangunan desa telah mengubah wajah desa yang sebelumnya tradisional, di mana masyarakat desa masih sangat tergantung hidupnya pada alam khususnya pertanian, menjadi desa yang swasembada, dimana interaksi desa dengan masyarakat di kota menjadi sangat lancar. Pada desa swasembada ini, mata pencaharian penduduk mulai beragam, tidak hanya pada pertanian, tetapi juga sektor lainnya, seperti industri manufaktur, perdagangan, dan jasa.

Rigg, dkk. (2001) menyebutkan bahwa keberagaman aktivitas dan diversifikasi pekerjaan di banyak pedesaan di Asia banyak dipengaruhi oleh kemajuan industrialisasi yang pesat yang membutuhkan tenaga kerja besar sehingga penduduk desa mulai beralih ke sektor industri. Selain itu, penghasilan pekerjaan non-pertanian lebih dapat diandalkan dan menjanjikan dibandingkan dengan penghasilan dari pertanian. Meskipun aktivitas di desa telah beragam, sektor pertanian tetap menjadi sumber penghidupan yang utama di desa. Sebagian besar masyarakat desa, khususnya di desa pertanian padi, termasuk dalam katagori petani kecil. Kategori pertanian kecil adalah petani dengan luas penguasaan lahan kurang dari satu hektare, meskipun tidak lagi sepenuhnya menggunakan tenaga kerja dari keluarga, seperti definisi Chayanov (1925), namun manajemen pengelolaan lahan tetap dilakukan pada level keluarga (Brookfield, 2008).

Perubahan struktur ekonomi dan sosial di desa, khususnya di Jawa, sudah tidak dapat lagi mengandalkan pertanian sebagai satusatunya mata pencaharian utama dan sumber pendapatan keluarga. Sebagian besar terdapat rumah tangga desa yang mempunyai kepala keluarga sebagai petani, namun juga tetap mempunyai pekerjaan sampingan, seperti buruh pabrik, pegawai bank, dan lain sebagainya. Desa tidak lagi didominasi kegiatan pertanian sebagai mata pencaharian utama penduduknya, namun lebih beragam sumber pendapatannya.

Sebelumnya, rumah tangga hanya mengandalkan kepala rumah tangga sebagai pencari nafkah keluarga, namun saat ini, istri juga terlibat dalam dunia kerja. Kesempatan kerja perempuan di desa semakin luas dengan masuknya pabrik-pabrik yang membutuhkan tenaga kerja perempuan. Letak geografis Klaten yang strategis dan ketersediaan pasokan tenaga kerja menjadi daya tarik bagi industri tekstil untuk mengoperasikan pabriknya di wilayah Klaten. Selain itu, terdapat pertumbuhan sektor perdagangan yang banyak melibatkan perempuan. Berdasarkan survei yang dilakukan di 3 desa, yaitu Pandes, Birit, dan Canan di Kecamatan Wedi dan Desa Sumyang di Kecamatan Jogonalan Kabupaten Klaten, 45 persen dari 62 ibu rumah tangga berstatus bekerja (Tabel 1). Keterlibatan ibu dalam pasar kerja mempengaruhi budaya-budaya pekerjaan domestik yang sebelumnya dilakukan sepenuhnya oleh ibu, terutama pengasuhan anak, penyajian makanan untuk keluarga, dan kegiatan domestik lainnya. Hasil pengamatan menunjukkan sebagian besar ibu yang bekerja menyerahkan pengasuhan anaknya, termasuk dalam penentuan jenis makanan yang akan disajikan untuk balitanya. Ketelatenan dan 
pengetahuan nenek atau pengasuh anak yang diperkerjakan sangat berperan dalam asupan nutrisi kepada balita.

Saat ini, perubahan budaya dari subsistence menjadi swasembada berpengaruh pada kemampuan akses pangan

Tabel 1. Status Bekerja Orang Tua yang Mempunyai Balita di 4 Desa Kabupaten Klaten

\begin{tabular}{llcc}
\hline \multicolumn{2}{c}{ Status Bekerja } & $\begin{array}{c}\text { Jumlah } \\
\text { Responden }\end{array}$ & $\%$ \\
\hline Bapak & Bekerja & 59 & $95 \%$ \\
& Tidak & & \\
& Bekerja & 2 & $3 \%$ \\
& Tidak & & \\
Ibu & Menjawab & 1 & $2 \%$ \\
& Bekerja & 28 & $45 \%$ \\
& Tidak & & \\
& Bekerja & 34 & $55 \%$ \\
\hline
\end{tabular}

Keterangan : Survei 62 Rumah Tangga

Sumber : IPSK LIPI (2018)

rumah tangga. Saat ini, akses pangan didasarkan pada kemampuan rumah tangga untuk membeli bahan-bahan pangan yang cukup. Pendapatan rumah tangga merupakan sumber utama dalam mengakses pangan bagi penduduk di Klaten. Data menunjukkan sebagian besar pendapatan rumah tangga antara satu sampai dengan tiga juta rupiah (Rp1.000.001-Rp3.000.000). Dari jumlah pendapatan tersebut, responden Desa Sumyang menyatakan kebutuhan untuk makan sehari-hari adalah proporsi terbesar dalam belanja rumah tangga. Sebagian besar pengeluaran responden per bulan sama responden dapat memenuhi kebutuhan pangan keluarga karena pendapatan yang diperoleh relatif sama atau di bawah dari pengeluaran rumah tangga. Di lain sisi, analisis yang lebih kritis dalam pembacaan Tabel 2 adalah semakin besarnya ketergantungan rumah tangga di pedesaan pertanian pada penyediaan pangan yang berasal dari pasar (pangan yang diperdagangkan) karena sebagian besar pendapatan digunakan untuk membeli makanan. Kemampuan rumah tangga untuk mendapatkan makanan dari hasil produksi sendiri hampir tidak ada. Dalam kondisi demikian, pergerakan harga pangan di pasar berdampak langsung pada kemampuan rumah tangga dalam mengakses pangan.

Dalam hal budaya pangan di tingkat masyarakat, petani Klaten melaksanakan kegiatan wiwitan. Wiwitan dilakukan oleh masyarakat sebagai bagian bentuk syukur kepada Tuhan menjelang panen raya. Masyarakat menyediakan makanan seperti nasi tumpeng, ayam/bebek, tahu, tempe, sayuran, dan buah-buahan yang mereka gunakan untuk makan bersama di pinggir sawah dan sebagian ditinggal di sawah untuk persembahan para penjaga sawah. Selain sebagai tradisi budaya, makan besar ini juga memberikan asupan makanan yang beragam, termasuk untuk masyarakat miskin yang sebelumnya sangat sulit untuk mendapatkan makanan. Namun sejak tahun 2000-an, budaya wiwitan semakin berkurang karena tidak semua desa di wilayah Klaten merayakannya. Bagi pihak yang masih merayakan saat ini, jumlah dan keragaman

Tabel 2. Pendapatan dan Pengeluaran Per Bulan Rumah Tangga di 4 Desa Kabupaten Klaten

\begin{tabular}{rccc}
\hline Pendapatan (Rp) & $\begin{array}{c}\text { Jumlah } \\
\text { Responden }\end{array}$ & Pengeluaran (Rp) & $\begin{array}{c}\text { Jumlah } \\
\text { Responden }\end{array}$ \\
\hline $500.000-1.000 .000$ & 11 & $500.000-1.000 .000$ & 14 \\
$1.000 .001-2.000 .000$ & 31 & $1.000 .001-2.000 .000$ & 31 \\
$2.000 .001-3.000 .000$ & 12 & $2.000 .001-3.000 .000$ & 13 \\
$3.000 .001-4.000 .000$ & 6 & $3.000 .001-4.000 .000$ & 3 \\
$4.000 .001-5.000 .000$ & 1 & $4.000 .001-5.000 .000$ & 1 \\
$5.000 .001-7.000 .000$ & 1 & & 62 \\
\hline Jumlah Responden & $\mathbf{6 2}$ & Jumlah Responden & \\
\hline
\end{tabular}

Keterangan : Survei 62 Rumah Tangga

Sumber : IPSK LIPI (2018)

dengan pendapatannya, yaitu antara satu hingga tiga juta rupiah (Tabel 2). Secara makanan juga berkurang dibandingkan umum, data menunjukkan bahwa pendapatan sebelumnya. 


\subsection{Karakteristik Konsumsi Pangan Rumah Tangga dan Kondisi Kesehatan Balita : Kasus pada Rumah Tangga dengan Anak Penderita Stunting di Desa Sumyang, Kecamatan Jogonalan}

Desa Sumyang adalah desa yang berada di Kecamatan Jogonalan, Kabupaten Klaten. Desa ini berpenduduk 1.920 jiwa dan terdiri dari 576 Kepala Keluarga. Enam puluh persen (1.117 jiwa) penduduk di desa tergolong penduduk dengan usia produktif, yaitu 16-60 tahun. Sementara itu, 8 persen (149 jiwa) adalah penduduk dengan usia 0-5 tahun (balita). Delapan puluh persen penduduk bekerja di pertanian dan setengahnya adalah petani sawah dengan status mempunyai lahan dan sebagian lainnya adalah buruh tani. Desa Sumyang termasuk desa dengan tingkat balita stunting yang tertinggi dibandingkan dengan desa lainnya di Kecamatan Jogonalam. Pada pencatatan balita di Posyandu Kecamatan Jogonalan, terdapat 10 balita di desa Sumyang yang mengalami stunting. Dari 10 balita tersebut, terdapat 2 balita yang mengalami gizi buruk, 5 balita mengalami status kekurangan gizi, dan hanya 3 yang memiliki stautus gizi normal. Pada kasus status gizi normal, stunting lebih disebabkan ketidakseimbangan nilai gizi dari makanan tersebut daripada karena kurangnya kuantitas makanan (Tabel 3).

Berdasarkan karakteristik ekonomi orang tua, rata-rata pekerjaan orang tua pada balita penderita stunting adalah buruh, baik buruh pertanian, maupun buruh bangunan. Rata-rata penghasilan orang tua per bulan adalah Rp1.000.000 sampai dengan Rp2.000.000. Keterbatasan penghasilan menyebabkan orang tua tidak dapat memenuhi gizi seimbang untuk balita. Strategi yang dilakukan ibu pada anak yang menderita stunting masih belum maksimal. Ketelatenan penyediaan makanan beragam ibu untuk balitanya masih kurang. Sebagian besar ibu hanya mengandalkan makanan tambahan yang diberikan oleh posyandu atau membeli makanan bayi instan. Dalam hal pemberian ASI Eksklusif, hasil survei rumah tangga di Klaten (Lestari, dkk., 2018) menunjukkan 34,4 persen ibu yang mempunyai balita usia 0-24 tahun tidak memberikan ASI Eksklusif, bahkan sebanyak 26,2 persen tidak memberikan ASI selama 6 (enam) bulan penuh setelah anaknya dilahirkan. Sebanyak 8,2 persen responden menyatakan masih menyusui anaknya yang berusia kurang dari 6 (enam) bulan.

Tabel 3. Status Balita Stunting di Desa Sumyang, Kecamatan Jogonalan

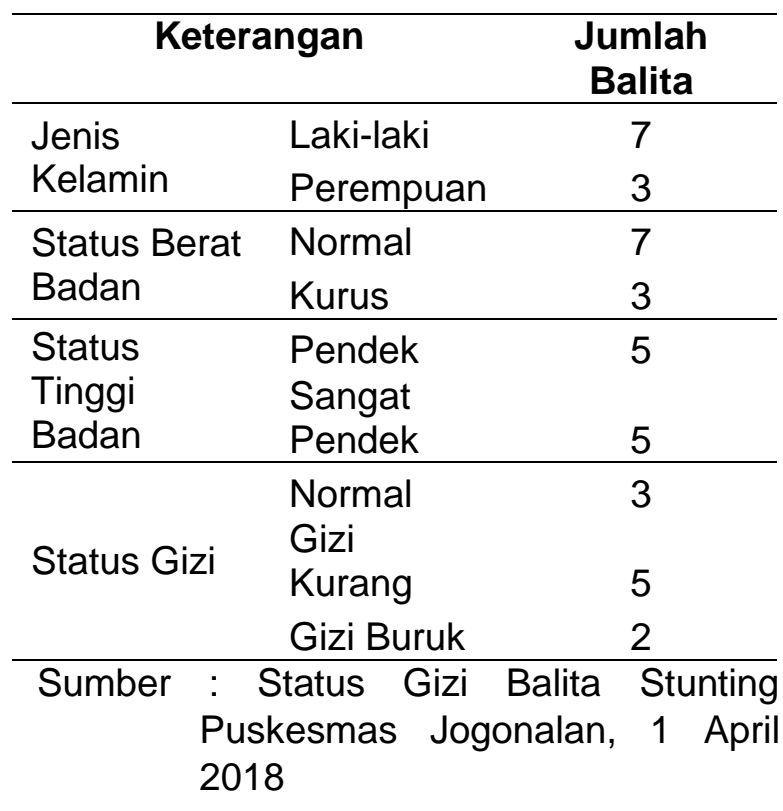

Rata-rata usia ibu yang mempunyai anak stunting adalah 35 tahun dan separuhnya berstatus berkerja. Rata-rata jam yang dihabiskan untuk berkerja sebanyak 8 jam per hari sehingga pengasuhan balita diserahkan kepada keluarga terdekat yang tinggal di desa yang sama. Hampir seluruh balita stunting tidak mendapatkan ASI eksklusif dan menggunakan MPASI instan yang dibeli di pasar atau di warung.

Beberapa contoh perilaku konsumsi balita stunting dapat dilihat dari ilustrasi Bayi J. Bayi $\mathrm{J}$ berusia16 bulan dengan berat badan $7,2 \mathrm{~kg}$ dan tinggi badan $72 \mathrm{~cm}$. Bayi J tergolong dalam balita stunting. Keluarganya termasuk dalam keluarga miskin dan memperoleh bantuan Gakin. Sebelum berusia 6 bulan, Bayi J mendapatkan ASI dan tambahan susu formula. Saat berusia 6 bulan ke atas sampai dengan saat ini, pola makan Bayi $\mathrm{J}$ relatif tidak beragam. Menu pagi yang disajikan adalah bubur nasi tanpa lauk pauk yang dibeli di warung sekitar desa. Sementara, menu siang hanya makan 2 telur rebus dan hanya dimakan pada bagian putih telurnya saja. Sore hari, Bayi J makan nasi dengan lauk telur goreng dan hanya bagian putihnya juga. Pola makan seperti itu adalah menu yang selalu disajikan setiap harinya oleh orang tua. 
Setelah makan, biasanya Bayi $\mathrm{J}$ minum teh manis. Bayi $\mathrm{J}$ hampir tidak pernah makan sayur, begitu juga dengan pola makan ibu dari Bayi $J$ yang tidak makan sayur. Pola makan Bayi $\mathrm{J}$ di atas menggambarkan pola makan yang hampir sama dengan balita stunting lainnya di Desa Sumyang, dimana kurangnya gizi yang seimbang dan menyebabkan risiko stunting. Meskipun telur mengandung banyak protein, namun Bayi $\mathrm{J}$ hanya makan bagian putihnya saja dan kandungan gizi mikro lainnya dianggap oleh tenaga kesehatan masih kurang.

llustrasi kedua, Bayi R (berusia 1 tahun, 11 bulan) adalah bayi kembar yang saat ini mempunyai berat badan $9,2 \mathrm{~kg}$ dan tinggi badan $79 \mathrm{~cm}$. Ibu Bayi $R$ mengalami kekurangan Gizi Kronis (KEK) dana anemia saat hamil kedua. Sama seperti Bayi J, keluarga Bayi $R$ juga termasuk dalam keluarga miskin. Pola makan Bayi $R$ juga relatif kurang beragam. Setelah bangun tidur, Bayi R minum susu dan makanan tambahannya adalah bubur instan yang dibeli di warung. Pada malam hari, Bayi $R$ hanya makan nasi dan telur. Sayur dan protein hewani sangat jarang dimakan oleh Bayi R.

Dua ilustrasi balita stunting di atas menggambarkan permasalah yang sangat rumit. Penderita stunting bukan hanya terjadi karena kurangnya gizi pada ASI maupun MPASI. Namun, terdapat beberapa faktor terbesar yang langsung berkaitan dengan terjadinya stunting di Desa Sumyang antara lain i) faktor ekonomi keluarga yang sebagian besar tergolong keluarga miskin; ii) pola pengasuhan yang kurangnya ketelatenan ibu dalam memberikan asupan gizi pada balita; iii) takaran susu biasanya kurang dari yang dianjurkan pada ibu yang memberikan tambahan susu formula; (iv) asupan makanan hanya mengandalkan pada makanan yang disukai oleh balita sehingga nutrisi diberikan kurang bervariasi atau gizi berimbang; dan (v) ibu hamil mengalami Kekurangan Energi Kronis (KEK) dan juga kekurangan sel darah yang mengandung hemoglobin (anemia).

Sanitasi dan ketersediaan air bersih tidak menjadi permasalahan serius di Desa Sumyang. Hampir seluruh rumah di desa memiliki sanitasi yang baik dan air sumur yang digunakan untuk makan dan minum tidak tercemar. Wilayah Sumyang mendapatkan aliran air yang cukup banyak dari lereng Gunung Merapi dan Merbabu sehingga hampir tidak terjadi kejadian kekurangan air untuk keperluan minum, makan, mandi, dan kebersihan lainnya. Pengelolaan air bersih di Klaten juga mendapat bantuan dari perusahaan minuman yang menyediakan saluran air bersih dari mata air ke desa-desa. Begitu juga kebutuhan air untuk pertanian, irigasi yang berasal dari mata air Merbabu dan Merapi di lokasi penelitian selalu terisi, meskipun pada musim kemarau.

Kabupaten Klaten termasuk dalam kabupaten yang mendapat prioritas pemerintah pusat sebagai wilayah pengurangan stunting. Desa Pandes, Kecamatan Wedi juga termasuk sebagai desa percontohan dalam pengurangan stunting. Program-program pengurangan stunting juga dirasakan oleh Desa Sumyang, meskipun akselarasi penurunan stuntingnya tidak secepat Desa Pandes, bahkan tingkat balita stunting di Desa Sumyang termasuk paling tinggi (meskipun secara jumlah balita stunting bukan tertinggi. Hal tersebut disebabkan karena penduduk Desa Sumyang tidak sebanyak desa lainnya. Program pengurangan stunting masuk melalui puskesmas, posyandu, dan kader-kader kesehatan di tingkat kecamatan dan desa. Program berkaitan langsung dengan pengurangan stunting di desa, mulai dari program untuk ibu hamil, program untuk balita, dan program untuk remaja putri.

Program untuk ibu hamil dilakukan sampai dengan 2 tahun lamanya. Program ibu hamil meliputi pemberian kelas tentang KEK dan anemia yang dilakukan setahun sekali. Dalam kelas ini, ibu hamil juga diberikan suplemen penambah darah. Efektivitas kelas ini untuk mengurangi kejadian ibu hamil KEK dan anemia sangat tergantung dengan kesadaran ibu hamil dalam mengkonsumsi suplemen penambah darah yang diberikan dan mengkonsumsi makanan dengan nutrisi yang cukup. Beberapa kasus ibu hamil yang melahirkan bayi stunting, masih banyak ibu yang mengalami KEK dan anemia. Hal tersebut juga disebabkan oleh pola makan ibu hamil khususnya pada kebutuhan protein dan vitamin yang juga kurang. 
Program pada bayi usia 0-5 tahun merupakan program yang paling banyak dilakukan. Program tersebut mencakup : i) pemberian ASI dan MPASI; ii) pemantauan berat badan dan tinggi bayi sampai dengan umur 5 tahun; iii) pemantauan status gizi balita; iv) pemberian informasi dalam pengasuhan balita untuk menghindari stunting; dan v) kunjungan ke rumah-rumah balita yang mengalami stunting untuk memberikan coaching kepada orang tua dalam penangan anak stunting. Selain dalam bentuk informasi, pemberian susu tambahan dan makanan tambahan juga dilakukan untuk bayi yang mengalami kekurangan gizi.

Sementara itu, program untuk remaja putri dilakukan melalui sosialisasi di sekolah pada tingkat SMP dan SMA/SMK. Sosialisasi dilakukan untuk pencegahan dan penangan anemia dan KEK yang terjadi pada remaja putri. Selain sosialisasi, dilakukan juga pemberian tablet penambah darah yang setiap minggunya diberikan melalui sekolah. Pada program ini, tidak terlihat bagaimana pemantauan dinas kesehatan di kecamatan untuk dapat memastikan bahwa remaja putri tersebut mengkonsumsi tablet penambah darah dan kemungkinan terjadinya anemia dan KEK.

Berbagai program-program tersebut diarahkan dalam mengembalikan status gizi bayi yang mengalami stunting. Pemberian makanan tambahan dapat mengurangi stunting di wilayah tersebut karena balita mendapatkan suntikan asupan makanan yang cukup. Namun dalam jangka panjang, pemberian suplemen tambahan tidak cukup untuk mengurangi angka stunting. Di daerah tersebut, permasalahan struktural juga menjadi faktor pendorong yang kuat dalam permasalahan pola asuh balita dan kondisi ibu hamil. Keterbatasan ekonomi, cara mengakses pangan yang mengandalkan dengan membeli, dan mengubah kebiasaan ibu untuk lebih kreatif dan telaten dalam memberikan makanan ke balita menjadi faktor yang sangat penting untuk diperhatikan dalam mengurangi balita stunting di Desa Sumyang.

\section{KESIMPULAN}

Beberapa kesimpulan yang dapat dirumuskan pada kasus stunting di Kabupaten Klaten antara lain :
Pertama, penyebab stunting di Klaten merupakan permasalahan multidimensi yang membutuhkan penanganan dari berbagai aspek. Salah satunya adalah akses pangan rumah tangga. Perubahan struktural pada masyarakat pertanian di Kabupaten Klaten mengubah wajah pedesaan yang sebelumnya pertanian subsistence berubah menjadi desa swasembada yang monokultur menyebabkan sebagian besar kebutuhan makanan rumah tangga diperoleh dengan cara membeli pangan di pasar, baik untuk pangan yang mengandung karbohidrat, protein, maupun vitamin lainnya.

Kedua, di tengah ketergantungan akses pangan sehari-hari penduduk Klaten dengan membeli di pasar, jumlah rumah tangga miskin masih tinggi, yaitu 14,46 persen (BPS, 2016), sehingga sebagian besar pendapatan masyarakat digunakan untuk membeli makanan dan rentan terhadap perubahan harga.

Ketiga, keterbatasan pasokan makanan yang beragam di tingkat rumah tangga karena keterbatasan ekonomi keluarga yang berdampak langsung pada kebiasaan konsumsi pangan yang beragam. Keluarga yang mempunyai balita stunting cenderung tidak menyukai makanan yang beragam, khususnya sayur mayur dan makanan laut.

Empat, peningkatan partisipasi ibu ke dunia kerja, khususnya ibu yang mempunyai anak stunting, menyebabkan terbatasnya waktu yang digunakan untuk pengasuhan anak dan menyiapkan makanan untuk anak sehingga kebiasaan "jajan" sudah menjadi kebiasaan sehari-hari.

Lima, membiasakan masyarakat untuk mengonsumsi pangan yang beragam tidak cukup dengan memberikan sosialisasi, seperti yang selama ini telah dilakukan. Namun juga, perlu dimulai dari peningkatan kemampuan rumah tangga untuk mendapatkan pangan yang beragam melalui bantuan non-tunai pangan, serta memperluas akses masyarakat mendapatkan berbagai jenis pangan antara lain dengan membudayakan kembali pemanfaatan lahan pekarangan dan pematang sawah untuk menanam sayur dan 
buah-buahan, serta membudidayakan ikan dan ternak.

\section{UCAPAN TERIMA KASIH}

Penulis mengucapkan terima kasih kepada Kedeputian IImu Sosial dan Kemanusiaan Lembaga IImu Pengetahuan Indonesia (LIPI) yang telah memfasilitasi penelitian ini yang juga merupakan bagian dari kajian cepat pengurangan stunting dalam program Widyakarya Pangan dan Gizi 2018. Penulis juga mengucapkan terimakasih banyak kepada tim kajian cepat (Bu Haning, Esta, Yuly, Puguh, Chichi, dan Anastasia) yang bersamasama melakukan pengambilan data.

\section{DAFTAR PUSTAKA}

[BMKG] Badan Meteorologi Klimatologi dan Geofisika. 2017. Situasi Ketahanan Pangan di 100 Kabupaten Prioritas Pengurangan Stunting. Buletin Pemantauan Ketahanan Pangan. Vol 9.

[BPS] Badan Pusat Statistik. 2016. Survei Sosial Ekonomi Kabupaten Klaten. Badan Pusat Statistik Kabupaten Klaten, Jawa Tengah.

Brookfield, H. 2008. Family Farms Are Still Around: Time to Invert The Old Agrarian Question. Geography Compass. Vol. 2(1). : 108-126.

Chayanov, A. V. 1925. Organizatsiya krest'yanskogo khozyaistva. Moskva. Tsentral'noe Tovarichestvo Kooprativnogo, Rusia.

Deller, S., Canto A., dan Brown L. 2017. Food Access, Local Foods, and Community Health. Community Development. Vol. 48(5). : 657680.http://doi.org/10.1080/15575330.2017.135 8197.

Dini, N.I., Siti F.P, dan Suyatno. 2017. Hubungan Konsumsi Makanan Jajanan terhadap Status Gizi (Kadar Lemak Tubuh dan IMT/U) pada Siswa Sekolah Dasar. Jurnal Kesehatan Masyarakat. Vol. 5(1). : 301-306.

Infodatin. 2016. Situasi balita pendek di Indonesia. Kementerian Kesehatan, Jakarta.

Jákl, J. 2015. Bhoma's Kitchen: Food Culture and Food Symbolism in Pre-Islamic Java. Global Food History. Vol. 1(1). : 33-57. http://doi.org/10.1080/20549547.2015.1143541 1.

[Kemenkes] Kementerian Kesehatan. Data Riset Kesehatan Dasar. 2018. Kementerian Kesehatan, Jakarta.

[Kemenkes] Kementerian Kesehatan. Data Riset Kesehatan Dasar. 2013. Kementerian Kesehatan, Jakarta.
Krasevec, J., Xiaoyi, A., Richard, K., France, B., dan Edward, A.F. 2017. Diet Quality and Risk of Stunting Among Infants and Young Children in Low- and Middle-Income Countries . Maternal and Child Nutrition. Vol.13(2). : 1-11. DOI: 10.1111/mcn.12430.

Lestari, E., Haning, R., Yuly, A., Ningrum, V., Anastasia, D.V., Prasetyoputra, P., Laksani, C.S. 2018. Mencegah Balita Stunting : Profiling Perilaku Ibu dalam Pengasuhan dan Konsumsi Pangan Kasus Kabupaten Klaten. Laporan Kajian Cepat. Lembaga IImu Pengetahuan Indonesia, Jakarta.

Ningrum, V. 2017. Pluriactivity di Pedesaan. In V. dan A. W. Ningrum (Ed.), Pemuda dan Pertanian Berkelanjutan. Pustaka Sinar Harapan, Jakarta.

Noble, H. dan Smith J. 2015. Issues of Validity and Reliability in Qualitative Research. Nurs April. Vol. 18(2). : 34-35. http://doi.org/10.1136/eb2015-102054.

Rachman, H. P. S. 2010. Aksesibilitas Pangan: Faktor Kunci Pencapaian Ketahanan Pangan di Indonesia. Pangan. Vol. 10 (1). : 157-156.

Rigg, J. 2001. More than the soil: rural change in Southeast Asia. Pearson Education, United Kingdom.

UNICEF, WHO, dan World Bank. 2018. Joint Malnutrition Estimates. May 2018 Edition : World Health Organization.

White, B. 2011. Who will own the countryside? Dispossession, rural youth and the future of farming. Valedictory Address delivered on 13 October 2011 on the occasion of the 59th Dies Natalis. (October). : 1-30.

\section{BIODATA PENULIS :}

Vanda Ningrum dilahirkan di Lampung, 20 September 1984. Penulis menyelesaikan pendidikan S1 di Fakultas Ekonomi, Universitas Indonesia pada tahun 2006 dan pendidikan S2 di ISIDA School of Business Italia pada tahun 2011. 